\title{
Khazanah
}

\section{BAGIR MANAN}

\begin{abstract}
"Pada negara kesatuan desentralistik, 'spanning' itu semacam pembawaan alami yang timbul karena tuntutan peran yang berbeda antara Pusat dan Daerah. Tetapi, karena kecenderungan yang satu akan merupakan pengorbanan dan kerugian pihak lain, harus ada upaya menemukan titik keseimbangan yang wajar demi keserasian hubungan. Hukumlah yang harus merintis jalan dan meletakan dasar-dasar keseimbangan itu". Bagir Manan
\end{abstract}

Rangkaian kalimat di atas merupakan cuplikan dari disertasi Prof. Bagir Manan yang berhasil dipertahankan di hadapan Sidang Terbuka di Universitas Padjadjaran pada tahun 1990 yang mengantarkannya lulus dengan predikat 'Cum Laude'. Dalam dunia hukum Indonesia, Bagir merupakan salah satu sosok yang berperan penting dalam pemikiran dan pengembangan pendidikan tinggi hukum. Hal lain yang tidak banyak dimiliki oleh kalangan ahli hukum adalah kemampuan serta aktivitasnya di dunia politik sebagai hasil keterlibatannya dalam pergerakan mahasiswa dalam menumbangkan rezim Orde Lama. Namun, pada bahasan Rubrik Khazanah ini hanya akan dikedepankan pemikiran Bagir dalam bidang hukum.

Bagir merupakan salah satu pemikir hukum terkemuka di Indonesia. Buah pikirannya jalin-menjalin (intertwine) antara filsafat hukum, teori hukum umum, serta teori hukum khusus, yakni teori hukum pada cabang ilmu hukum tertentu, misalnya ilmu hukum tata negara dan administrasi negara. Sekadar contoh, dalam teori hukum umum, misalnya, Bagir berpendapat Proklamasi Kemerdekaan 1945 merupakan grundnorm Indonesia ${ }^{1}$ karena Proklamasi menyebabkan tatanan hukum lama menjadi tidak ada dan menimbulkan serta memberikan dasar bagi keberadaan tatanan hukum baru. ${ }^{2}$ Suatu pandangan yang agak berbeda dengan para ahli hukum lain yang umumnya menempatkan Pancasila sebagai grundnorm. Dalam konteks sumber hukum tata negara, Bagir juga mempunyai pendapat yang berbeda, seperti misalnya dengan Alm. Prof. Usep Ranawijaya. Menurut Bagir, doktrin merupakan sumber hukum material, sebaliknya Alm. Usep meletakannya sebagai sumber hukum formal. Argumentasi yang dikemukakan Bagir ialah sumber hukum formal haruslah bersifat hukum. Namun, Bagir berusaha memahami pandangan yang memasukkan doktrin sebagai sumber hukum formal akibat

PADJADJARAN Jurnal IImu Hukum Volume 2 Nomor 3 Tahun 2015 [ISSN 2460-1543] [e-ISSN 2442-9325]

1 Bagir Manan, "Hukum Perundang-undangan di Indonesia" dalam Kuntana Magnar dan Mashudi (ed), Pertumbuhan dan Perkembangan Konstitusi Suatu Negara, Bandung: Mandar Maju, 1995, hlm 23.

2 Bagir Manan, Hukum Tata Negara Indonesia dalam Undang-Undang Dasar 1945 (akan terbit). 
pengaruh dari masa Romawi. ${ }^{3}$ Selain itu, kekuatan pemikiran Bagir ditopang oleh kemampuannya melakukan perbandingan hukum, khususnya hukum tata negara serta sejarah.

Dalam bidang pendidikan, meskipun tidak pernah menduduki jabatan struktural di almamaternya, Bagir mengembangkan pemikiran pendidikan tinggi hukum melalui kampus lain, yakni Universitas Islam Bandung dimana ia pernah menjadi Dekan dan Rektor yang memungkinkannya untuk memberikan corak kekhasan pendidikan tinggi hukum di perguruan tinggi berbasis Islam, yang membedakan dengan pendidikan tinggi lainnya. Keterlibatannya di berbagai lembaga menjadikan pemikiran Bagir pada bidang pendidikan tinggi hukum melengkapi pandangan beberapa ahli hukum yang berprofesi sebagai dosen, antara lain Prof. Mochtar Kusumaatmadja, Prof. Sunaryati Hartono, Prof. Marjono Reksodiputro, serta Alm. Prof. Arief Sidharta.

Jalinan pemikiran Bagir terlihat pada eksplanasi pemikiran-pemikirannya pada bahasan ini. Pada gilirannya jalinan pemikiran ini akan memberikan pemahaman bahwa membaca, memetakan, dan memahami pemikirannya secara utuh harus diletakkan pada keragaman dimensi seorang Bagir Manan: teoritisi, praktisi hukum (seorang hakim, anggota Dewan Perwakilan Rakyat Daerah, dan pejabat administrasi negara), serta tokoh gerakan mahasiswa 1966 yang membawanya terlibat dalam berbagai aktivitas politik.

\section{A. Sketsa Biografi ${ }^{4}$}

Deskripsi singkat biografi ini memperlihatkan pelangi perjalanan Bagir Manan yang melintasi berbagai bidang. Bidang akademik merupakan bidang pertama dan utama yang sangat dicintainya, berlanjut ke badan legislatif, eksekutif, serta yudikatif. Bidang pers menjadi pilihannya setelah menuntaskan pengabdiannya sebagai Hakim Agung dan Ketua Mahkamah Agung di tahun 2008.

Dilahirkan di Desa Kalibalangan Lampung tanggal 6 Oktober 1941 menjadikan Bagir hanya bercita-cita sebagai juru tulis di kecamatan, sebuah cita-cita sederhana dari seseorang yang menamakan dirinya sebagai anak desa. Namun, perjalanan hidup membawanya melampaui cita-cita sederhana itu. Bermula dari keputusannya melanjutkan studi di Fakultas Hukum Universitas Padjadjaran pada tahun 1960, Bagir mulai memperlihatkan kemampuannya di bidang akademik dan organisasi kemahasiswaan. Sebagaimana disampaikan oleh sahabatnya, Prof.

3 Bagir Manan, "Ajaran-ajaran Sumber-sumber Hukum Sebagai Dasar Hakim Memutus Perkara Menurut Hukum”, Monografi, 2014, hlm 2.

4 Informasi lengkap perjalanan hidup Bagir Manan, lihat Hikmat Kusumaningrat dan Purnama Kusumaningrat, 70 Tahun Prof. Dr. Bagir Manan, S.H., MCL: Ketekunan, Keteguhan, Kesabaran Memajukan Hukum dan Demokrasi, Bandung: Rosda-PSKN FH Unpad, 2011. 
Mieke Komar, Bagir sering mententeer sesama kawan sekelasnya, meskipun pada kurun waktu yang sama ia secara intensif terlibat dalam berbagai kegiatan kemahasiswaan, termasuk demonstrasi-demonstrasi menggulingkan rezim Orde Lama.

Lulus tepat waktu pada tahun 1965 dengan skripsi di bidang hukum adat membawa Bagir menjadi dosen di almamaternya. Menariknya, bidang kajiannya berubah menjadi hukum tata negara dan sosok di balik perubahan tersebut adalah Prof. Sri Soemantri yang berkeyakinan bahwa Bagir akan lebih berkembang di bidang hukum tata negara. Selang beberapa tahun kemudian, Bagir dipercaya menjadi anggota Dewan Perwakilan Daerah (DPD) Kota Bandung hingga periode awal 1970-an. Perkenalannya dengan Prof. Beverly Mae Carl dari Southern Methodist University Texas pada tahun 1970-an saat mengikuti kegiatan diskusi mingguan bagi dosen-dosen muda Fakultas Hukum Universitas Padjadjaran, menyadarkan pentingnya memperoleh wawasan yang lebih luas melalui pendidikan di luar Indonesia. Pelatihan tersebut tidak saja membuka jalan mengikuti jenjang pendidikan lanjutan, melainkan termasuk pula memberikan ilmu pengetahuan yang lebih kuat di bidang filsafat dan teori hukum sebagai tambahan materi yang pernah diterimanya di bangku kuliah. Hal itu tidak lain karena salah satu pengajarnya adalah Prof. Mochtar Kusumaatmadja, kemudian menarik Bagir menjadi salah satu staf ahli di Kementerian Kehakiman. Keterlibatannya sebagai staf ahli menjadikan Bagir mulai melakukan pengkajian bidang perancangan perundang-undangan.

Pada tahun 1980-an, Bagir berkesempatan melanjutkan jenjang pendidikan S2 di Southern Methodist University dan berhasil meraih gelar Master of Comparative Law. Semula Bagir berniat segera melanjutkan ke jenjang S3 tak lama sepulang dari Dallas karena Bagir telah mengumpulkan bahan-bahan disertasi mengenai uji materil (judicial review). Namun, karena 'alasan-alasan yang bertentangan dengan tradisi ilmiah, saya (Bagir Manan) terkena seleksi Menteri atau atas nama Menteri, sebagai yang tidak diperkenankan menulis disertasi'. ${ }^{5}$ Prof. Sri Soemantri kembali turun tangan mengatasi keadaan ini dan berakhir dengan keluarnya izin studi bagi Bagir. Atas saran Sri Soemantri, yang kemudian menjadi Ketua Tim Promotor, Bagir mengubah bidang penelitian dari semula uji materil menjadi otonomi daerah. Judul lengkap disertasinya adalah "Hubungan Antara Pusat dan Daerah Menurut Asas Desentralisasi Berdasarkan UUD 1945". Beberapa konsep penting yang dihasilkan dalam disertasi tersebut kemudian menjadi dasar-dasar atau prinsip-prinsip pemerintahan daerah dalam UUD 1945 Perubahan, akan diuraikan pada bagianbagian di bawah ini.

5 Bagir Manan, "Menemukan Kembali Undang-Undang Dasar 1945", Pidato Mengakhiri Jabatan Sebagai Guru Besar, Fakultas Hukum Universitas Padjadjaran, Bandung, 6 Oktober 2011, hIm 26. 
Sebagaimana telah disebutkan, keterlibatan Bagir di Kementerian Kehakiman dimulai sejak menjadi staf ahli yang diteruskan tak lama setelah menyelesaikan S3 pada tahun 1990 seiring pengangkatannya sebagai Direktur Perundang-undangan yang kemudian berlanjut pada pencapaian menjadi Direktur Jenderal Hukum dan Perundang-undangan. Pada masa itu berbagai undang-undang penting lahir, misalnya Undang-Undang Keimigrasian yang mengakhiri mekanisme cegah dan tangkal (cekal) yang semula dilakukan tanpa batas waktu menjadi dibatasi untuk waktu tertentu. ${ }^{6}$

Pada kurun waktu 2000-2008, pengabdian Bagir pada negara berlanjut. Pada Maret 2000, ia diangkat menjadi anggota Komisi Ombudsman Nasional bersamasama dengan Antonius Sujata, Prof. Sunaryati Hartono, Teten Masduki, R.M. Surachman, Masdar F. Mas'udi, dan Sri Urip. Komisi Ombudsman Nasional merupakan sebuah lembaga baru yang didirikan pada masa pemerintahan Presiden Abdurahman Wahid yang memiliki mandat utama melakukan pengawasan penyelenggaraan negara, termasuk bidang peradilan, serta menciptakan suasana kondusif untuk pemberantasan korupsi, kolusi dan nepotisme. Suatu mandat yang sangat luas, yang menurut Bagir selain tidak sesuai dengan mandat Ombudsman klasik yang sangat menekankan pada pengawasan terhadap administrasi negara, juga dapat menimbulkan kesulitan bagi Komisi Ombudsman Nasional. Pada masa pengabdian yang cukup singkat, Bagir bersama-sama dengan Prof. Sunaryati Hartono menjadi tulang punggung Komisi ini untuk mempersiapkan rancangan undang-undang tentang Ombudsman yang bertujuan memperkuat fungsi lembaga ini dalam struktur ketatanegaraan Indonesia.

Pada tahun 2000 pula, Prof. Yusril Ihza Mahendra, yang saat itu menjabat Menteri Hukum dan Perundang-undangan, mengajukan Bagir menjadi salah satu calon hakim agung dari jalur non-karir (usulan pihak Pemerintah) ke Dewan Perwakilan Rakyat (DPR) bersama sejumlah akademisi hukum lain, yakni Prof. Muladi, Prof. Laica Marzuki, dan Prof. Valerine Kierkhoff. Tanpa menemui hambatan berarti, Bagir terpilih menjadi hakim agung. Selain penguasaan ilmu hukum yang sangat memadai, fit and proper test yang harus ditempuh tidak menjadi halangan baginya karena beberapa tokoh utama DPR saat itu merupakan sahabat-sahabatnya sejak terlibat pada masa pergerakan mahasiswa. Dengan kata lain, kemampuan ilmu yang menunjukkan profesionalisme dan jejaring yang kuat serta luas menjadi faktor yang cukup menentukan dalam proses tersebut.

5 Mei 2001 merupakan puncak perjalanan di bidang penyelenggaraan negara saat Presiden Abdurahman Wahid mengangkatnya menjadi Ketua Mahkamah Agung. Menyadari menyandang amanat yang berat, Bagir segera menyusun strategi pembenahan dunia peradilan Indonesia. Dalam suasana reformasi dan harapan

6 Lihat Undang-Undang Nomor Tahun 1992 tentang Keimigrasian. 
tinggi yang diletakkan di pundaknya, Bagir memperkenalkan cara baru melakukan reformasi internal peradilan dengan melibatkan berbagai civil society organization untuk membantunya membuat cetak biru reformasi peradilan yang berisi tahapantahapan pembaharuan peradilan.

Saat menjadi Ketua Mahkamah Agung, kontribusi lain yang tidak kalah penting berkenaan dengan problem-problem konstitusional yang berkaitan dengan penyelesaian masalah Aceh yang mengemuka saat terjadinya perundingan antara Pemerintah Indonesia dan Gerakan Aceh Merdeka (GAM). Prof. Hamid Awaluddin, yang menjabat Menteri Hukum dan HAM dan sekaligus menjadi Ketua juru runding Pemerintah Indonesia saat itu, menjelaskan salah satu sumbangan pemikiran yang sangat menentukan berhasil tidaknya perundingan datang dari Bagir mengenai kehadiran politik lokal sebagaimana dituntut oleh GAM. ${ }^{7}$ Menghadapi ketiadaan ketentuan hukum positif mengenai hal itu, Bagir berpendapat bahwa: pertama, tidak terdapat larangan dalam konstitusi adanya partai politik lokal; dan kedua, dalam rangka kekhususan Aceh dibandingkan dengan daerah otonom lainnya.

Kontribusi lain yang tidak kalah penting dalam kerangka penyelesaian masalah Aceh adalah pemberian amnesti bagi pengikut GAM. Gagasan ini bermula dari Wakil Presiden Jusuf Kalla yang ditindaklanjuti secara teknis oleh Hamid Awaluddin. Ketika itu, Bagir menyatakan:

"Amnesti itu, Bung, adalah mekanisme dan instrumen konstitusi untuk menutup luka lama. Jadi, sekarang ini jangan Bung berpikir boleh tidaknya memberikan amnesti. Tapi, Bung harus berpikir, dengan amnesti luka lama kita tutup. Lembaran buram masa lalu kita tutup dan kita melihat ke depan". ${ }^{8}$

"Dari universitas biduk saya layarkan, saya berharap di universitas biduk ini saya labuhkan" adalah kalimat yang diucapkan Bagir dalam Sidang Pleno Mahkamah Agung sebagai Pidato Perpisahan Ketua Mahkamah Agung tahun 2008. Ucapan itu membuktikan kecintaannya pada dunia pendidikan yang membawanya kembali ke Universitas Padjadjaran mengabdikan ilmu serta membimbing para dosen di Fakultas Hukum Universitas Padjadjaran, khususnya di Departemen Hukum Tata Negara. Tahun 2011, Bagir mengakhiri hubungan kedinasan secara resmi di Universitas padjadjaran saat menginjak usia 70 tahun. la berpesan "bagi anda-anda yang bekerja di kampus, tanamkan selalu bahwa kampus adalah lembaga ilmiah tempat persemaian, perkembangan, dan pemikiran ilmu yang bermanfaat untuk kemanusiaan, peradaban, dan keselamatan umat manusia". ${ }^{9}$ Pesan khusus disampaikannya kepada para dosen hukum tata negara, sebagai berikut:

\footnotetext{
7 Hikmat Kusumaningrat dan Purnama Kusumaningrat, Op.cit, hlm. 251.

8 Ibid., hlm. 259.

9 Bagir Manan, “Menemukan Kembali Undang-Undang...”, Op.cit, hlm. 28.
} 
"Ilmu hukum tata negara bukanlah ilmu yang sangat netral, karena itu tidak selalu aman dan nyaman. Ilmu hukum tata negara adalah salah satu cabang ilmu kenegaraan, sangat erat bersentuhan dengan organisasi dan sistem kekuasaan yang tidak selalu sejalan dengan asas, kaidah, dan konsep ilmu hukum tata negara. Tanpa karakter atau kepribadian yang kuat, ahli hukum tata negara dapat menjadi alat kekuasaan belaka. Saya berharap kalian tetap teguh dengan prinsip-prinsip keilmuan yang bertanggung jawab. Jadilah selalu peniup sangkakala apabila kekuasaan tidak lagi bekerja demi kepentingan dan kebaikan bersama". ${ }^{10}$

Tak lama setelah menyampaikan pidato perpisahan, kalangan Pers melalui Aliansi Jurnalis Independen (AJI) mencalonkannya menjadi anggota Dewan Pers dari perwakilan masyarakat. Seperti sudah diduga, Bagir tanpa mengalami kesulitan terpilih menjadi anggota, bahkan, secara aklamasi dipilih menjadi Ketua Dewan Pers selama dua periode yaitu 2011-2013 dan 2013-2016. Pada masa kepemimpinannya, Dewan Pers melakukan berbagai program strategis dalam rangka penguatan kebebasan pers, antara lain, melalui konsistensi penegakan Kode Etik serta kerjasama dengan lembaga-lembaga pemerintah dan non-pemerintah dari dalam dan luar negeri.

\section{B. Hukum Pemerintahah Daerah sebagai IImu"}

Dari sekian banyak pemikiran Bagir mengenai pembelajaran hukum pemerintahan daerah, terdapat dua hal penting yang patut dicermati: Pertama, letak hukum pemerintahan daerah dalam cabang ilmu kenegaraan. Negara dengan segala selukbeluknya (jabatan-jabatan, pejabat-pejabat, tugas dan wewenang, hak dan kewajiban, serta cara mengelola negara) menjadi objek penyelidikan berbagai ilmu kenegaraan yang dapat dibagi menjadi ilmu hukum kenegaraan dan ilmu kenegaraan umum. Ilmu hukum kenegaraan, misalnya, ilmu hukum tata negara, ilmu hukum administrasi negara, ilmu hukum pemerintahan daerah, dan ilmu hukum konstitusi. Ilmu politik, ilmu negara, dan ilmu administrasi pemerintahan merupakan contoh-contoh ilmu kenegaraan umum.

Ditinjau dari obyek penyelidikan, hukum pemerintahan daerah sekaligus masuk pada dua cabang ilmu hukum, yakni hukum tata negara dan hukum administrasi negara. Oleh karenanya, untuk mencapai comprehensiveness, pengajaran, atau pembelajaran hukum pemerintahan daerah harus menggunakan pendekatan kedua cabang ilmu tersebut di atas. Hukum tata negara menurut ajaran Logemann adalah hukum yang mempelajari organisasi negara. Pemerintahan daerah adalah

\footnotetext{
10 Ibid., hlm. 28-29.

11 Bagir Manan, “Hukum Pemerintahan Daerah", Makalah, Kuliah Umum Fakultas Hukum Universitas Lampung, 13 Februari 2010.
} 
organisasi negara tingkat lebih rendah atau dapat disebut sebagai sub-organisasi negara. Dengan demikian, hukum mengenai pemerintahan daerah merupakan bagian dari hukum organisasi negara yang menjadi objek hukum tata negara. Hal ini dapat dibuktikan dari buku-buku tentang hukum tata negara yang memuat bab mengenai pemerintahan daerah atau otonomi. Selain itu, hukum pemerintahan daerah masuk ke dalam kajian hukum administrasi negara. Hukum administrasi negara adalah hukum yang mengatur cara-cara pemerintah (administrasi negara) menjalankan pemerintahan (menjalankan administrasi negara), yang mencakup:

1. Hukum yang mengatur internal administrasi negara;

2. Hukum yang mengatur hubungan administrasi dengan warga atau penduduk negara;

3. Hukum yang mengatur hak dan kewajiban warga atau penduduk terhadap pemerintah (administrasi negara).

Dengan demikian, jika mengkaji hukum pemerintahan daerah hanya mengenai tata cara pemerintahan daerah menjalankan pemerintahan (administrasi negara), maka kajian hukum ini masuk ke dalam rumpun hukum administrasi negara. Sebagai ilmu yang berdiri sendiri, hukum pemerintahan daerah merupakan hukum administrasi negara khusus sebagai hasil pengembangan hukum administrasi negara umum.

Kedua, dasar-dasar pembelajaran hukum pemerintahan daerah. Sejak tahun 1980-an, hukum pemerintahan daerah diajarkan di berbagai Fakultas Hukum atau Sekolah Tinggi Hukum di Indonesia. Pengajaran ini menurut Bagir semula didasarkan pada alasan-alasan praktis semata, yaitu akibat pemberlakukan satuan kredit semester, penggenapan mata kuliah, menguatnya spesialisasi keilmuan serta keperluan pendalaman materi tertentu (khususnya pada strata pendidikan lanjutan). Argumentasi praktis ini menurutnya tidak kuat untuk dijadikan sebagai basis atau landasan, karena Bagir berpendapat mendalami hukum di fakultas hukum pada dasarnya adalah mempelajari hukum sebagai suatu ilmu. Oleh karena itu, menjadi penting memberikan pembenaran pembelajaran atas dasar syaratsyaratilmu.

Bagir berpendapat, hukum pemerintahan daerah merupakan satu cabang ilmu yang berdiri sendiri atas dasar empat kriteria, yaitu:

\section{Bahan-bahan hukum}

Bahan-bahan hukum ini berfungsi sebagai sumber hukum yang meliputi:

a. Bahan hukum berupa teori-teori atau konsep-konsep tentang pemerintahan daerah atau otonomi, misalnya teori sistem rumah tangga dan hubungan pusat dan daerah;

b. Bahan hukum berupa hukum tertulis, berupa peraturan perundang-undangan, mulai dari Undang-Undang Dasar, undang-undang, peraturan pemerintah, 
Peraturan Presiden, peraturan menteri, sampai pada tingkat daerah yakni peraturan daerah, bahkan peraturan desa. Selain itu, dapat pula dijumpai berbagai peraturan kebijakan yang ditetapkan oleh Pemerintah Pusat maupun pemerintah daerah; dan

c. Bahan hukum tidak tertulis, misalnya hukum adat yang masih berlaku, praktikpraktik pemerintahan daerah, serta putusan-putusan hakim.

\section{Hubungan dengan Cabang atau Disiplin Ilmu Hukum Lain}

Sebagaimana dijelaskan, hukum pemerintahan daerah dapat didekati dari dua cabang ilmu, yaitu hukum tata negara dan hukum administrasi negara. Selain itu, hukum pemerintahan daerah dapat pula mempunyai hubungan dengan ilmu-ilmu lain diluar ilmu hukum, misalnya dengan ilmu politik, ilmu pemerintahan. Aneka ragam hubungan (keterkaitan) tersebut menunjukkan kekayaan analisis hukum pemerintahan daerah. Menyikapi hal ini, Bagir berpendapat:

"Membiarkan kajian hukum pemerintahan daerah menjadi bagian aneka ragam disiplin ilmu, sehingga berserak-serak menyebabkan tidak ada kebulatan kajian yang terintegrasi. Hal ini bukan saja menimbulkan kesulitan praktis karena terpecah-pecah, tetapi juga kesulitan konseptual yang akan menghalangi pengembangan teori dan konsep hukum pemerintahan daerah yang mandiri. Menjadikan hukum pemerintahan daerah sebagai cabang atau disiplin ilmu hukum yang berdiri sendiri lebih memungkinkan pengembangan konsep atau teori hukum pemerintahan daerah yang mandiri". ${ }^{12}$

\section{Sifat Khusus}

Sifat khusus ini berkenaan dengan fungsi-fungsi pemerintahan daerah atau otonomi, yang meliputi: fungsi manajemen, pelayanan publik, politik, polisionil atau penegakan ketertiban, keragaman, dan penjagaan persatuan. Untuk memahami fungsi-fungsi tersebut maka dibutuhkan penggunaan metode yang bersifat interdisipliner yang tidak hanya bermanfaat bagi pengkajian, melainkan pula untuk pembentukan dan penerapan. Pengayaan ini dapat pula diperoleh dari penggunaan metode perbandingan.

\section{Kajian-kajian yang Sudah Ada}

Pemerintahan daerah dikaji oleh beragam cabang ilmu, baik ilmu hukum maupun ilmu-ilmu sosial lainnya. Bahkan, dalam ilmu ekonomi telah dikembangkan kajiankajian mengenai sistem akuntansi pemerintahan daerah. Keseluruhan dan kekayaan kajian-kajian ini makin menguatkan pentingnya hukum pemerintahan daerah sebagai cabang ilmu yang berdiri sendiri.

Sebagai konsekuensi bahwa pengajaran hukum pemerintahan daerah dilakukan atas dasar-dasar teori serta dasar hukum positif, maka materi pembelajaran terbagi menjadi dua bagian utama, yaitu:

\footnotetext{
12 Ibid., hlm. 8-9.
} 
a. Materi pengajaran umum bersifat teoritis yang antara lain meliputi: istilah dan pengertian hukum pemerintahan daerah, sistem rumah tangga daerah, hubungan pemerintahan daerah dan bentuk negara, serta asas-asas penyelenggaraan pemerintahan daerah;

b. Materi pengajaran khusus yang berkenaan dengan hukum positif yang akan berubah dari waktu ke waktu sebagai akibat terjadinya perubahan peraturan perundang-undangan, praktik penyelenggaraan pemerintahan daerah, serta putusan hakim.

\section{Dasar Konstitusional dan Asas-asas Penyelenggaraan Pemerintahan Daerah}

Menurut Bagir, salah satu kegagalan penyelenggaraan pemerintahan daerah atau otonomi di Indonesia disebabkan lemahnya pengaturan mengenai hal ini dalam UUD 1945. Sebelum perubahan, UUD 1945 hanya mengatur materi pemerintahan daerah secara sumir yang pada gilirannya menghasilkan politik otonomi yang tidak jelas dan tegas. Penyebabnya, "struktur UUD 1945 banyak mengatur ketentuan organik (undang-undang organik), tanpa disertai arahan tertentu materi muatan yang harus diikuti atau dipedomani" ${ }^{13}$ Oleh karenanya, materi muatan akan ditentukan oleh pembentuk undang-undang. Salah satu contoh nyata adalah perbedaan antara Undang-Undang Nomor 22 Tahun 1948 dengan Undang-Undang Nomor 18 Tahun 1965, Undang-Undang Nomor Tahun 1974 serta Undang-Undang Nomor 22 Tahun 1999, meskipun seluruh undang-undang tersebut memiliki dasar konstitusi yang sama, yaitu Pasal 18 UUD 1945. Perbedaan menyolok terutama terlihat antara Undang-Undang Nomor 5 Tahun 1974 yang bersifat sangat sentralistik dengan Undang-Undang Nomor 22 Tahun 1999 yang sangat desentralistik. Dalam bahasa Bagir, bandul atau pendulum senantiasa bergerak dari satu titik ekstrem ke titik ekstrem lainnya. ${ }^{14}$ Perubahan semacam ini dapat menggoyahkan sendi-sendi penyelenggaraan otonomi Indonesia.

Tahun 1999 saat dorongan dilakukannya perubahan UUD 1945 mencapai puncaknya, meskipun gagasan perubahan Pasal 18 mulai disinggung, namun materi perubahan lebih diprioritaskan pada cabang kekuasaan legislatif, eksekutif, serta yudikatif. ${ }^{15}$ Pembahasan intensif mulai dilakukan tahun 2000, dan Bagir berkesempatan merealisasikan konsep-konsep mengenai pemerintahan daerah atau otonomi di Indonesia sebagaimana telah ditulis dalam disertasinya tahun 1990. Saat itu, ia diminta sebagai salah satu anggota Tim Ahli atau Tim Pakar Panitia

13 Bagir Manan, Teori dan Politik Konstitusi, FH UII Press: Yogyakarta, 2003, hlm 16.

${ }^{14}$ Bagir Manan, Menyongsong Fajar Otonomi Daerah, Pusat Studi Hukum Fakultas Hukum UII: Yogyakarta, 2001, hlm 46.

15 Mahkamah Konstitusi, Naskah Komprehensif Perubahan Undang-Undang Dasar Negara Republik Indonesia Tahun 1945: Latar Belakang, Proses, dan Hasil Pembahasan 1999-2002, Buku IV Kekuasaan Pemerintahan Negara, Jilid 2, Sekretariat Jenderal dan Kepaniteraan Mahkamah Konstitusi: Jakarta, 2008, hlm 118-119. Lihat pula Bagir Manan, Teori dan Politik..., Op.Cit., hlm. 3. 
Ad Hoc I (PAHI) Badan Pekerja Majelis Permusyawaratan Rakyat (MPR). Dalam salah satu kesempatan, ketika diminta pendapatnya mengenai pentingnya perubahan Pasal 18, Bagir mengatakan bahwa perubahan perlu dilakukan karena berbagai anomali lahir dari bunyi Penjelasan Pasal 18 yang dipandangnya bertentangan dengan Pasal 18. Dikatakan bertentangan karena Pasal 18 hanya mengatur tentang otonomi daerah, sedangkan Penjelasan mengatur tentang satuan administrasi atau dekonsentrasi. ${ }^{16}$ Dekonsentrasi adalah bagian dari sentralisasi, oleh sebab itu harus diatur dalam organisasi pemerintahan pusat, bukan dalam pemerintahan daerah. ${ }^{17}$

Elaborasi pemikiran-pemikiran Bagir terlihat dengan jelas saat masa perumusan norma-norma tentang pemerintahan daerah dalam PAH I Badan Pekerja MPR (BP MPR). ${ }^{18}$ Dapat dikatakan Bagir berada dibelakang perbaikan rancangan norma-norma tersebut, karena tampaknya anggota-anggota PAH I hanya menyampaikan bahan mentah atau konsep dasar. ${ }^{19}$ Saat salah seorang anggota menanyakan masuknya konsepsi baru yang tidak sesuai dengan bahan mentah, ${ }^{20}$ Bagir secara lugas menjawab bahwa tidak ada kesengajaan memasukkan konsepsi baru. Pandangan tersebut muncul karena pertanyaan tim ahli mengenai pengertian pemerintahan daerah dan hal-hal lain yang relevan tidak terjawab oleh anggota PAH I. Oleh sebab itu, tim ahli berusaha 'mencari jawaban sendiri, mencoba berdasarkan yang ada pada kami...tidak ada maksud untuk jauh-jauh dari konsep-konsep itu'. ${ }^{21}$

Pada tanggal 18 Agustus 2000, MPR menyetujui perubahan Bab Pemerintahan Daerah dalam UUD 1945. Secara konseptual maupun hukum, pasal-pasal baru pemerintahan daerah memuat paradigma-paradigma baru dan arah politik pemerintahan daerah yang baru pula, yang tampak dari prinsip-prinsip sebagai berikut: ${ }^{22}$

1. Daerah mengatur dan mengurus sendiri urusan pemerintahan menurut asas otonomi dan tugas pembantuan sebagaimana diatur dalam Pasal 18 ayat (2). Berbeda dengan Pasal 18 lama, pada ketentuan baru ini ditegaskan bahwa dalam pemerintahan daerah hanya ada pemerintahan otonom sehingga pemerintahan yang didasarkan atau bersifat 'administrasi belaka' tidak lagi mendapat dasar konstitusional. Hal ini sekaligus menjelaskan bahwa dekonsentrasi tidak lagi digunakan sebagai asas penyelenggaraan pemerintahan daerah karena menurut Pasal ini hanya dikenal dua asas, yakni otonomi dan tugas pembantuan;

2. Otonomi seluas-luasnya sebagaimana diatur dalam Pasal 18 ayat (5). Otonomi

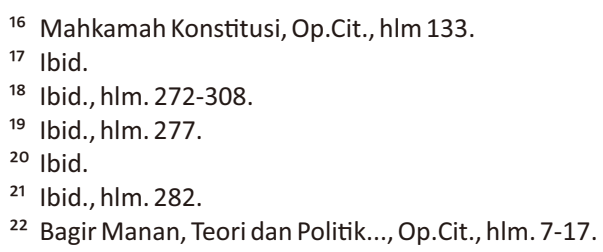


luas berarti seluruh urusan merupakan urusan daerah, kecuali urusan yang secara tegas dinyatakan sebagai urusan Pusat. Prinsip otonomi luas ini sejalan dengan kehendak penyusun UUD 1945 saat sidang Badan Penyelidik Usaha Persiapan Kemerdekaan (BPUPK), sebagaimana disampaikan oleh Ratulangi, yang antara lain menyatakan, "supaya daerah pemerintahan di beberapa pulau-pulau besar diberi hak seluas-luasnya untuk mengurus keperluannya sendiri, tentu dengan memakai pikiran persetujuan, bahwa daerah-daerah itu adalah daripada Indonesia", ${ }^{23}$

3. Kekhususan dan keragaman daerah sebagaimana diatur dalam Pasal $18 \mathrm{~A}$ ayat (1). Prinsip ini bermakna bahwa isi otonomi tidak selalu harus sama atau bersifat uniformitas, melainkan didasarkan pada keadaan-keadaan khusus atau keragaman daerah;

4. Pengakuan dan penghormatan terhadap kesatuan masyarakat hukum adat beserta hak-hak tradisionalnya sebagaimana diatur dalam Pasal 18B ayat (2). Yang dimaksud dengan masyarakat hukum adat adalah masyarakat hukum yang berdasarkan hukum adat atau adat istiadat desa, seperti desa, marga, nagari, gampong, meunasah, huta, dan lain-lain. Keberadaan kesatuan masyarakat hukum adat haruslah 'sepanjang masih hidup' dan hak-hak tradisional ini harus sejalan dengan perkembangan masyarakat dan Negara Kesatuan Republik Indonesia. Bagir berargumen bahwa pembatasan yang dimuat dalam frasa 'sepanjang masih hidup' dimaksudkan untuk menunjukkan sebagai 'kenyataan sosial dalam masyarakat yang bersangkutan, bukan sesuatu hal hukum itu secara sosiologis sudah tidak ada lagi, tetapi hanya mempunyai nilai-nilai historis saja', ${ }^{24}$

5. Pengakuan dan penghormatan pemerintahan daerah yang bersifat khusus dan istimewa sebagaimana diatur dalam Pasal 18 B ayat (1). Dalam bunyi Penjelasan UUD 1945 sebelum perubahan, 'bersifat istimewa' menunjuk pada pemerintahan asli atau pemerintahan bumiputra, sehingga menurut Penjelasan ini daerah khusus tidak dikenal. ${ }^{25}$ Keberadaan daerah khusus dalam praktiknya semata-mata didasarkan pada undang-undang, misalnya Daerah Khusus Jakarta sebagaimana diatur dengan Undang-Undang Nomor 27 Tahun 2009. Namun, saat ini pengertian kekhususan tidak lagi semata-mata menunjuk pada Provinsi Daerah Khusus Ibukota Jakarta, melainkan diperluas meliputi Provinsi Nanggroe Aceh Darussalam, dan Provinsi Papua;

6. Badan perwakilan dipilih langsung dalam suatu pemilihan yang terdapat dalam Pasal 18 ayat (3). Prinsip ini sejalan dengan ketentuan yang berlaku bagi keanggotaan DPR yang juga dipilih secara langsung. Namun, pengisian jabatan

\footnotetext{
23 Ibid., hlm. 11.

${ }^{24}$ Mahkamah Konstitusi, Naskah Komprehensif Perubahan..., Op.Cit., hlm. 283.

25 Bagir Manan, Teori dan Politik..., Op.Cit, hlm. 15.
} 
gubernur, walikota, dan bupati tidak dilakukan secara langsung, melainkan 'dipilih secara demokratis';

7. Hubungan pusat dan daerah harus dilaksanakan secara selaras dan adil sebagaimana diatur dalam Pasal 18A ayat (2). Diakui oleh Bagir tidak ada satu ukuran tertentu mengenai hubungan yang adil dan selaras, namun ketentuan ini hendak menunjukkan bahwa daerah berhak memperoleh secara wajar segala sumber daya untuk mewujudkan penyelenggaraan pemerntahan daerah yang mandiri dalam kerangka mewujudkan kesejahteraan masyarakat di daerahnya. ${ }^{26}$

\section{Hubungan Pusat dan Daerah}

Dari berbagai dimensi hubungan pusat dan daerah, Bagir berpendapat terdapat empat dimensi utama yang dapat diidentifikasi, meliputi: ${ }^{27}$

\section{Hubungan Kewenangan}

Hubungan ini berkenaan dengan cara pembagian urusan atau cara menentukan urusan rumah tangga daerah, yang sekaligus akan mencerminkan bentuk otonomi terbatas atau otonomi luas. Suatu bentuk dikatakan sebagai otonomi terbatas apabila tunduk pada kriteria sebagai berikut:

a. Urusan rumah tangga ditentukan secara katagoris dan pengembangannya dilakukan dengan cara-cara tertentu;

b. Sistem pengawasan sangat ketat yang mengakibatkan hilangnya kemandirian daerah dalam menyelenggarakan urusan rumah tangganya;

c. Sistem keuangan yang tidak memungkinkan Daerah secara maksimal mengembangkan pendapatan asli daerah. ${ }^{28}$

\section{Hubungan Keuangan}

Salah satu titik penting menjaga hubungan yang serasi antara Pusat dan daerah adalah hubungan keuangan karena hubungan ini (seperti juga hubungan kewenangan dan hubungan pengawasan) akan sangat menentukan kemandirian daerah. Makin tinggi tingkat ketergantungan daerah ke Pusat, maka diperkirakan akan makin rendah tingkat kemandirian suatu daerah. Berdasarkan premis ini, maka inti hubungan keuangan Pusat dan daerah adalah 'perimbangan keuangan'. ${ }^{29}$ Pemaknaan yang tepat untuk 'perimbangan keuangan' yakni, selain memungkinkan daerah menggali dan memperbesar sumber pendapatan asli, termasuk pula mengatur prinsip-prinsip sistem keuangan daerah yang berasal dari subsidi yang menyebabkan daerah tidak kehilangan kemandirian, keleluasaan untuk mengatur dan mengurus urusan rumah tangganya. ${ }^{30}$

\footnotetext{
26 Ibid., hlm. 17.

27 Bagir Manan, Menyongsong Fajar Otonomi, Op.Cit., hlm. 37-46.

28 Ibid., hlm. 37.

29 Ibid., hlm. 40.

30 Ibid., hlm 42. Bandingkan dengan pengertian hubungan keuangan menurut Undang-Undang Nomor 23 Tahun
} 


\section{Hubungan Pengawasan}

"Tidak ada otonomi tanpa pengawasan dan otonomi bukanlah kemerdekaan". Demikian Bagir selalu mengingatkan bahwa batas otonomi adalah Negara Kesatuan Republik Indonesia. Dengan kata lain, pengawasan merupakan "simbol negara kesatuan terhadap daerah otonom". ${ }^{31}$ Namun demikian, pengawasan tidak boleh mempersempit atau bahkan mengurangi kemandirian daerah dalam menyelenggarakan urusan rumah tangganya. Oleh karena itu, harus ditentukan batas-batas serta ruang lingkup pengawasan. Pengawasan umum sebagaimana pernah dijalankan oleh Undang-Undang Nomor 5 Tahun 1974, merupakan salah satu jenis pengawasan yang menurut Bagir dapat mempengaruhi kemandirian Daerah. $^{32}$ Saat ini pranata pengawasan umum diatur kembali dalam UndangUndang Nomor 23 Tahun 2014.

\section{Hubungan Keorganisasian}

Hubungan ini berkenaan dengan susunan organisasi pemerintahan daerah yang mengandung dua segi, yaitu susunan luar (external structure) dan susunan dalam (internal structure). ${ }^{33}$ Susunan luar menunjuk pada badan-badan pemerintahan (publieklichaam) tingkat daerah seperti provinsi, kota, kabupaten, atau dengan kata lain menunjuk pada susunan pemerintahan. Bagir menyatakan bahwa semua satuan pemerintahan tingkat daerah harus tersusun dalam satu kesatuan integral. ${ }^{34}$ Sedangkan, susunan dalam berkenaan dengan alat kelengkapan (organ) pemerintahan daerah, seperti kepala daerah dan DPRD. Untuk mengetahui apakah penyelenggaraan pemerintahan daerah cenderung ke arah sentralisasi atau desentralisasi dalam konteks susunan dalam maka dapat digunakan indikatorindikator berupa fungsi dan kedudukan organ kelengkapan, termasuk tugas, wewenang, serta cara pengisian jabatan. ${ }^{35}$

\section{E. Pendidikan Tinggi Hukum}

Pemikiran-pemikiran Bagir mengenai pendidikan tinggi hukum sangat didorong oleh kecemasannya terhadap mutu para lulusan yang makin merosot. Baginya, 'pendidikan tinggi hukum (the higher legal education) sebagaimana pendidikan tinggi lainnya adalah lembaga pengajaran keilmuan (scientific legal education, scientific legal teaching), bukan sekedar lembaga pendidikan atau pengajaran pengetahuan hukum (legal knowledge education, legal knowledge teaching).

\footnotetext{
2014, "suatu sistem pembagian keuangan yang adil, proporsional, demokratis, transparan, dan bertanggung jawa"'.

31 Bagir Manan, Hukum Tata Negara..., Loc.Cit.

32 Bagir Manan, Menyongsong Fajar Otonomi, Op.Cit., hlm. 39.

33 Bagir Manan, Hubungan Antara Pusat dan Daerah Menurut UUD 1945, Pustaka Sinar Harapan: Jakarta, 1994, hlm. 191-192.

34 Ibid., hlm. 256.

35 Ibid., hlm. 199.
} 
Dengan bahasa yang mudah, obyek pendidikan atau pengajaran di lembaga pendidikan tinggi hukum adalah ilmu hukum (legal science, rechtswetenshap)'. ${ }^{36}$

Sejalan dengan makna pendidikan tinggi hukum di atas, terdapat tiga isi atau content pengajaran pendidikan tinggi hukum, meliputi: ${ }^{37}$ Pertama; penguasaan teori hukum, sejarah hukum, dan filsafat hukum. Teori hukum meliputi teori hukum umum (general theory of law) dan teori hukum khusus, yakni teori dan konsep masing-masing cabang ilmu hukum. Sejarah hukum mengkaji, meneliti, dan mengajarkan sejarah pertumbuhan (perkembangan) hukum dan latar belakang aturan-aturan hukum. Filsafat hukum mengajarkan pengertian-pengertian hukum, hubungan hukum dengan kekuasaan, hubungan hukum dengan masyarakat, tujuan hukum, fungsi hukum, dasar-dasar kepatuhan kepada hukum, dan lain-lain objek yang dikaji secara kefilsafatan.

Kedua; penguasaan metode keilmuan atau metode ilmiah. Pengkajian, penelitian, dan pengajaran keilmuan tidak dapat dipisahkan dari metode ilmiah, baik yang umum maupun yang khusus. Oleh sebab itu, metode selalu menjadi syarat kehadiran suatu ilmu, cabang ilmu, atau disiplin ilmu. Paling tidak, terdapat dua tujuan pengajaran metode keilmuan dalam ilmu hukum, yaitu:

1. Penguasaan cara berfikir sistematik. Setiap ilmu, cabang ilmu atau disiplin ilmu tersusun menurut atau berdasarkan sistematika tertentu untuk menjamin keutuhan (comprehensiveness) serta kepaduan (cohesiveness) sebagai suatu ilmu, cabang ilmu, atau disiplin ilmu. Hukum adalah sebuah sistem yang memiliki bermacam-macam sumber, baik formal maupun materil serta memiliki beberapa karakter, yaitu sebagai fenomena normatif atau fenomena sosial. Tanpa pengajaran metode hukum secara keilmuan sulit mengharapkan cara berpikir sistematik, yang pada gilirannya sulit mencapai penguasaan ilmu hukum dan ketrampilan hukum secara keilmuan dengan baik.

2. Penguasaan penalaran hukum atau legal reasoning. Secara sosiologis maupun normatif, hukum adalah hasil konstruksi logika yang timbul dari kebutuhan logis tertentu, seperti kebutuhan akan ketertiban, kesejahteraan, keadilan, suasana yang harmonis, kekuasaan, dan lain sebagainya. Oleh sebab itu, analisis hukum secara keilmuan harus senantiasa didasarkan pada berbagai hubungan logis tersebut, baik antar aturan hukum yang ada maupun hubungan dengan lingkungan tempat hukum berlaku. Melalui pengajaran legal reasoning, akan tercapai setidak-tidaknya hal-hal berikut:

a. Pemahaman secara tepat, dasar-dasar, dan alasan-alasan keberadaan

\footnotetext{
36 Bagir Manan, "Tantangan Pembangunan Hukum di Indonesia”, Makalah, Workshop Mata Kuliah Reformasi Hukum yang diselenggarakan oleh Program E2J, The Asia Foundation, Jakarta, 20 November 2013, hlm. 13.

37 Bagir Manan, "Kebutuhan dan Arah Pembaharuan Hukum di Indonesia", Makalah, Seminar tentang Profesionalisme Sarjana Hukum Dikaitkan Dengan Pendidikan Hukum, BPHN Kementerian Hukum dan HAM RI, Fakultas Hukum Unpad, Kanwil Kementerian Hukum dan HAM RI Provinsi Jawa Barat, Bandung, 4 Agustus 2010, hlm 2-5.
} 
suatu aturan hukum;

b. Memberi dasar aktualisasi hukum menghadapi berbagai perkembangan dan kebutuhan baru;

c. Memberi dasar bagi pembaharuan hukum.

Ketiga; pengajaran ketrampilan hukum secara keilmuan, yaitu keterampilan atas dasar ilmu hukum (scientific legal skill), bukan sekedar keterampilan yang bersifat pertukangan belaka (craftmanship) yang diperoleh semata-mata melalui latihan praktis atau suatu pengalaman biasa.

\section{F. Kontribusi dan Tanggapan}

Dari paparan-paparan di atas, dapat disimpulkan bahwa kontribusi-kontribusi pemikiran Bagir terlihat menonjol pada bidang hukum pemerintahan daerah. Bagir tidak saja mengembangkan teori-teori maupun konsep-konsep dalam tataran akademik sebagai hasil penelitiannya selama bertahun-tahun yang kemudian dituangkannya dalam bentuk disertasi, melainkan pula berkesempatan merealisasikannya dalam tataran praktik yang mengantarkannya sebagai salah satu konseptor sekaligus drafter Bab Pemerintahan Daerah UUD 1945 Perubahan. Saat menjelaskan pandangannya secara verbal, Bagir acap kali mengaitkannya dengan teori-teori hukum tata negara, dan tidak jarang pula dengan filsafat hukum dan teori-teori hukum umum. Hal tersebut terlihat dengan jelas saat Hamid Awaluddin meminta pandangannya berkenaan dengan masalah Aceh.

Basis teori yang sangat kuat menyebabkannya mampu menjawab persoalanpersoalan di masyarakat dan penyelenggaraan negara, di tengah-tengah terjadinya kekosongan norma peraturan perundang-undangan. Saat memberikan pandangan tentang keberadaan partai politik lokal misalnya, Bagir mengaitkannya dengan salah satu tujuan hukum, yakni memberikan manfaat bagi masyarakat. Bahkan, saat norma UUD 1945 menyediakan sarana amnesti dan Pemerintah berniat menggunakan sarana tersebut untuk para pengikut GAM, Bagir mendukung dan menyetujuinya karena baginya hukum harus mengupayakan tercapainya perdamaian di masyarakat. Bahkan, hukum dapat mendorong terjadinya rekonsiliasi di kalangan masyarakat Aceh.

Dalam perspektif teori hukum khusus, yaitu teori hukum tata negara, terutama berkenaan dengan sumber hukum, Nota Kesepahaman antara Pemerintah Indonesia dan GAM dapat dikatakan sebagai perjanjian politik. Jika merujuk pada pendapat Usep Ranawidjaja, perjanjian semacam ini diklasifikasikan sebagai sumber hukum dalam arti formal. ${ }^{38}$ Sebaliknya, jika didasarkan pada pandangan Bagir yang menyatakan bahwa sumber hukum formal haruslah mempunyai sifat hukum, maka Nota Kesepahaman tersebut dikategorikan tidak dapat dikategorikan sebagai sumber hukum dalam arti formal, melainkan sumber hukum materil yaitu

\footnotetext{
${ }^{38}$ Lihat, Usep Ranawidjaja, Hukum Tata Negara Indonesia: Dasar-dasarnya, Ghalia Indonesia: Jakarta, 1984, hlm 22.
} 
sumber yang menentukan isi atau materi hukum. Seperti diketahui pokok-pokok materi Nota Kesepahaman tersebut diatur lebih lanjut dalam Undang-Undang Nomor 11 Tahun 2006 tentang Pemerintahan Aceh.

Dalam konteks hukum pemerintahan daerah, terdapat beberapa point penting dari pemikiran Bagir yang menarik untuk disimak:

Pertama, otonomi adalah pengikat Negara Kesatuan Republik Indonesia. ${ }^{39}$ Otonomi mempunyai tanggung jawab mewujudkan kesejahteraan rakyat melalui fungsi-fungsi otonomi, yang meliputi fungsi manajemen, pelayanan, politik yang sangat erat kaitannya dengan demokrasi, polisionil, keragaman, dan persatuan. ${ }^{40}$ Pandangan Bagir mengenai otonomi dalam kaitan dengan demokrasi sangat dipengaruhi oleh pikiran Mohammad Hatta. Dalam salah satu tulisan, Hatta menyatakan:

"Oleh karena Indonesia terbagi atas beberapa pulau dan golongan bangsa, maka perlulah tiap-tiap golongan, kecil atau besar, mendapat autonomi, mendapat hak untuk menentukan nasib sendiri. Satu-satunya dapat mengatur pemerintahan sendiri menurut keperluan dan keyakinan sendiri, asal saja peraturan masing-masing tidak berlawanan dengan dasar-dasar pemerintahan umum". ${ }^{41}$

Demokrasi yang berintikan kebebasan memungkinkan daerah menyelenggarakan urusannya sendiri, termasuk membuat dan menjalankan peraturan yang dibuatnya. Meskipun demokrasi juga dapat dijumpai dalam sistem pemerintahan yang sentralistik, namun Hans Kelsen menyatakan bahwa desentralisasi lebih memungkinkan terlaksananya demokrasi atau kedaulatan rakyat. ${ }^{42}$

Kedua, dasar-dasar hubungan antara Pusat dan daerah dalam kerangka desentralisasi yang meliputi: dasar permusyawaratan dalam sistem pemerintahan negara; dasar pemeliharaan dan pengembangan prinsip-prinsip pemerintahan asli; dasar kebhinnekaan; dan dasar negara hukum. ${ }^{43}$ Keseluruhan dasar tersebut tercermin dalam norma-norma UUD 1945 mengenai pemerintahan daerah, yang selanjutnya menjadi politik otonomi daerah. ${ }^{44}$ Dalam kaitan ini, Bagir membagi politik otonomi daerah menjadi dua bagian, yakni politik hukum yang dijalankan pada tingkat nasional, dan politik hukum yang dilaksanakan pada tingkat daerah. Berkenaan dengan politik hukum di tingkat nasional, perlu diperhatikan hal-hal yang berkaitan dengan jaminan pelaksanaan otonomi seluas-luasnya, jaminan perimbangan keuangan, pengakuan dan penghormatan tatanan asli daerah,

\footnotetext{
39 Lihat Bagir Manan, Fajar Otonomi, Op.Cit., hlm. vii.

40 Bagir Manan, "Tugas Sosial Pemerintahan Daerah", Makalah, 2009.

41 Dikutip dalam Bagir Manan, Hubungan Antara Pusat..., Op.Cit., hlm 33.

42 Hans Kelsen, General Theory of Law and State, Russel\&Russel: New York, 1945, hlm. 312.

${ }^{43}$ Bagir Manan, Hubungan Antara Pusat..., Op.Cit., hlm. 161-170.

${ }^{44}$ Bagir Manan, "Politik Hukum Untuk Otonomi Daera”', Makalah Kuliah Umum Program Pasca Sarjana, FH Universitas Syah Kuala, Banda Aceh, 23 September 2013, hlm 10-14.
} 
jaminan kekayaan alam digunakan secara adil.

Adapun politik hukum yang dilakukan oleh daerah lebih menekankan pada fungsi pelayanan umum untuk mewujudkan keadilan sosial, kesejahteraan umum, kemakmuran rakyat daerah. Dengan perkataan lain, politik hukum di daerah lebih diarahkan pada pengembangan hukum-hukum kesejahteraan, yang antara lain meliputi: ${ }^{45}$

1. Peraturan-peraturan yang bertalian dengan jaminan sosial seperti jaminan kesehatan, pendidikan;

2. Peraturan-peraturan yang berkaitan dengan pembangunan sosial seperti pemberdayaan ekonomi rakyat seperti pengembangan usaha kecil-menengah dan koperasi;

3. Peraturan-peraturan yang berkaitan dengan kenyamanan dan keamanan sosial seperti kebersihan, kelancaran transportasi, pertamanan;

4. Peraturan-peraturan yang berkaitan dengan perlindungan sosial, seperti peraturan ketertiban dan keamanan;

5. Peraturan-peraturan yang berkaitan dengan akses-akses sosial, seperti kemerdekaan informasi dan kemerdekaan komunikasi.

Dalam perkembangan terkini, politik hukum pada level daerah sejajar atau sejalan dengan konsep hak atas kota (the right to city). Pada akhir tahun 1960-an, tepatnya 1968, seorang filsuf Perancis Henri Lefebvre memperkenalkan the right to city (hak atas kota). Hak ini tidak hanya menggarisbawahi terpenuhinya akses masyarakat yang hidup di perkotaan, melainkan lebih esensial merupakan sebuah hak untuk mengubah diri melalui perubahan kota. Ditinjau dari hubungan dengan rakyat, fungsi pemerintahan modern adalah memberi pelayanan terbaik kepada rakyat (the service state).

Pelayanan merupakan pekerjaan konkrit pemerintah terhadap rakyat dan pekerjaan ini hanya akan berhasil apabila pemerintah mengetahui secara pasti hajat hidup rakyat yang memerlukan pelayanan. Hal tersebut hanya mungkin diwujudkan kalau satuan pemerintahan didekatkan dengan rakyat. Inilah salah satu fungsi pemerintahan otonom, yaitu agar lebih dekat dengan rakyat yang wajib dilayani. Dalam konteks ini, pengarusutamaan hak asasi manusia (human rights mainstreaming) menjadi penting karena seluruh pelayanan dilaksanakan dan dimaksudkan dalam rangka pemenuhan hak asasi manusia. Disinilah dalam pandangan saya menjadi titik temu konsep hak asasi manusia (khususnya hak atas kota) dengan pelayanan publik.

Ketiga, dekonsentrasi bukanlah asas penyelenggaraan pemerintahan daerah, melainkan cara menyelenggarakan urusan pemerintahan pusat di daerah. Oleh sebab itu, dekonsentrasi tidak dapat diletakkan sebagai bagian dari sistem

45 Ibid, hlm 14. 
pemerintahan daerah yang merupakan 'anti tesis dari sentralisasi'. ${ }^{46}$ Meskipun tidak diatur dalam UUD 1945, kehadiran dekonsentrasi tidak diartikan sebagai inkonstitusional karena penggunaan dekonsentrasi tidak dapat dielakkan sejalan dengan kenyataan bahwa sejumlah urusan masih dimiliki oleh Pusat. Dengan kata lain, dalam negara kesatuan yang disertai otonomi tidak mungkin meniadakan dekonsentrasi di daerah. Oleh karenanya, tarik menarik antara dekonsentrasi dan otonomi akan senantiasa ada. Persoalannya, 'bagaimana eksistensi dekonsentrasi dan tarik menarik dengan otonomi. Apakah akan memberikan manfaat sebesarbesarnya bagi kesejahteraan umum dan keadilan sosial rakyat daerah'. ${ }^{47}$

Otonomi dan dekonsentrasi acap kali digambarkan sebagai dua kutub yang senantiasa menimbulkan 'spanning' atau 'tension' dalam penyelenggaraan pemerintahan (administrasi negara). Dekonsentrasi mewakili sentralisasi. Otonomi mewakili desentralisasi. Spanning atau tarik menarik timbul karena beberapa hal: ${ }^{48}$

1. Dekonsentrasi disebut mewakili rezim sentralisasi, baik atas dasar pengendalian, menjamin kesatuan dan persamaan perlakuan (uniformitas). Otonomi mewakili desentralisasi untuk menjamin demokratisasi pemerintahan, bertolak dari kenyataan riil di setiap daerah, dan efisiensi;

2. Tatanan politik demokrasi yang lazimnya diikuti dengan sistem pemencaran kekuasaan, baik secara vertikal maupun horizontal. Salah satu fungsi pemencaran kekuasaan demokratis adalah memaksimalkan keikutsertaan dalam penyelenggaraan negara dan pemerintahan. Di pihak lain, tatanan politik otoriter senantiasa cenderung pada sentralisasi untuk mengontrol segala aspek penyelenggaraan negara dan pemerintahan, termasuk mengontrol segala bentuk kegiatan masyarakat.

3. Pengaruh konsep negara kesejahteraan yang menimbulkan tanggung jawab kepada negara dan pemerintah untuk turut serta dalam pergaulan masyarakat. Salah satu akibatnya, urusan pemerintahan menjadi makin meluas yang mempengaruhi cara pembagian fungsi pemerintahan antara Pusat dan daerah.

4 Efektivitas sifat dan cakupan setiap urusan pemerintahan yang mengakibatkan tidak mudah menentukan suatu urusan layak dimasukkan sebagai urusan dekonsentrasi atau otonomi.

\section{Susi Dwi Harijanti}

\footnotetext{
46 Bagir Manan, Fajar Otonomi, Op.Cit., hlm 11.

47 Bagir Manan, “Dekonsentrasi Dalam Penyelenggaraan Otonomi Luas Berdasarkan Undang-Undang Dasar 1945”, Pidato Pertanggungjawaban Akademik Selaku Ketua Tim Promotor a.n. Iskatrinah, Bandung, 22 Mei 2015, hlm 3.

48 Ibid., hlm. 2.
} 